\title{
Global social issues in the curriculum: perspectives of school principals
}

\section{Venka Simovska \& Åsa Kremer Prøsch}

To cite this article: Venka Simovska \& Åsa Kremer Prøsch (2015): Global social issues in the curriculum: perspectives of school principals, Journal of Curriculum Studies, DOI: 10.1080/00220272.2015.1114150

To link to this article: http://dx.doi.org/10.1080/00220272.2015.1114150

册 Published online: 25 Nov 2015.

Submit your article to this journal $₫$

Q View related articles $\sqsubset$

View Crossmark data \lceil 


\title{
Global social issues in the curriculum: perspectives of school principals
}

\author{
Venka Simovska and Åsa Kremer Prøsch \\ School of Education, Aarhus University, Copenhagen, Denmark
}

\begin{abstract}
In this article, we discuss principals' perspectives on the priority given to the place in the curriculum of and the supporting practices related to health and sustainability education in schools in Denmark (for pupils aged 6-16). The study is situated within the discourses about critical health and sustainability education and treats the two issues as societal challenges that are important to address in schools as educational examples. We draw on the literature on school leadership challenges linked to global neoliberal trends in educational reform. The context of the study is the ongoing school reform in Denmark. The data were generated through an online survey of principals in Denmark $(n=118)$. The findings show that although the principals view school as an important arena for health and sustainability education, their actual support for such education lags behind. Health education is prioritized somewhat more than sustainability education; however, both are characterized by insufficient attention to teachers' professional development and the low prioritization of collaboration within the school and between the school and community actors. Acknowledging the contradicting demands that principals face in the context of the reform, we argue for reconnecting the concept of leadership with the wider purposes of schooling and for providing space for an emergent, whole-school curriculum that addresses health and sustainability.
\end{abstract}

\section{KEYWORDS}

Schools; curriculum; health; sustainability; principals

\section{Introduction}

Schools play a crucial role in developing the competencies and motivation necessary for students to engage with key societal challenges, including those related to health and sustainability. Health and sustainability are among the greatest challenges of the contemporary world, and schools face increasing demand to include these topics in pedagogical practices and everyday school life. Both issues are important not only as topics to be covered in particular subjects but also as fundamental principles for schools' academic and organizational development; they concern wider social and societal determinants as well as individual behaviour, and address both public and private domains of action. Both health and sustainability are underpinned by high-level transnational policies (e.g. United Nations, 2008; 
United Nations Educational, Scientific, Cultural Organization [UNESCO], 2012; World Health Organization [WHO], 1986, 2013) and represent a distinct complexity that calls for wholeschool development and pedagogies that are interdisciplinary, participatory and action oriented (Gough, 2005; Jackson, 2009; Madsen, Nordin, \& Simovska, 2015; Young, 2015). At the same time, such pedagogical practices face a number of obstacles in the context of existing educational policy landscapes, which are increasingly shaped by global competitiveness and neoliberal values; this influence is reflected in the prioritization of developing knowledge, skills and attitudes that are primarily linked to the labour market and economic growth, which often entail a focus on measurable, internationally comparable learning outcomes and result-oriented curricula with an emphasis on 'core' subjects (i.e. the mother language, mathematics and science). This tendency, characterized by performativity and accountability, is evident in educational reforms worldwide (Cheng, 2002, 2011). In Denmark (Danish Ministry of Education, 2014a; Moos, 2014), such priorities have already influenced the framework for health and sustainability education (Madsen et al., 2015).

Some of the questions that could be asked in this respect include: How is room provided for pedagogical practices that address complex and contested social issues, such as health and sustainability? What place do these pedagogies, which focus on developing pupils' comprehensive abilities to reflect and act on incomplete knowledge, conflicting interests and uncertainty (McNamara \& Simovska, 2015), have in contemporary measurement-driven school reforms that emphasize straightforward, quantifiable learning outcomes in clearly delineated mono-disciplinary subjects? What are the roles and responsibilities of school leaders in this respect, and what dilemmas and challenges do they face?

Making room for interdisciplinary, cross-curricular themes and for related 'real-world'oriented pedagogical practices in schools requires embedding these themes and practices into the schools' priorities and visions. This process places specific demands upon school principals. Scholarship in the fields of school-based health education, health promotion and education for sustainable development, although scarce, indicates the importance of principals planning, implementing and monitoring the effectiveness of such pedagogical practices. Studies within the health-promoting schools paradigm (Clift \& Bruun Jensen, 2005; McNamara \& Simovska, 2015) have indicated the essential role that principals play in the effective implementation of school-based health promotion and education (e.g. Inchley, Muldoon, \& Currie, 2006; Samdal \& Rowling, 2015; Viig, Fosse, Samdal, \& Wold, 2011; Viig \& Wold, 2005). Furthermore, research has noted the significance of school principals' attitudes towards health issues in determining the position of health education in the curriculum; Hargreaves (2013), for example, suggests that when principals do not value health education and when their attitude is that 'everyone can teach health', health education is given lower priority, limited resources are made available and there is limited awareness among the school staff of the links between education and health. Research has also emphasized the value of supporting principals' roles related to health-promotion activities in schools through training, supervision and communication resources (Dadaczynski \& Paulus, 2015).

In a similar line, scholarship in the field of education for sustainable development has identified the following dimensions of school leadership that are conducive to integrating global social issues into pedagogical practices: distributed leadership, which encourages a wide scope of participation in schools' decision-making processes; a shared vision of the school's goals; and attention to wider social issues in the local community and globally (Jackson, 2007; Symons, 2008). These dimensions echo the 'paradigm shift' debated in the general school 
leadership literature and underline the shift from instrumental to transformational leadership (Hallinger, 2010), that is leadership that emphasizes school effectiveness in the context of the concurrent globalization, localization and individualization of education (Cheng, 2002, 2011).

Against this backdrop, in this article, we examine principals' perspectives on the importance of, the priority given to, the place in the curriculum of and the supporting practices related to health education and sustainable development education in primary and lower secondary schools in Denmark (i.e. among pupils aged 6-16). We begin by placing the study within the context of Danish basic education, the framing of school leadership and the position of the two themes, health and sustainability, in the newly revised national curriculum as a part of the ongoing reform of Danish primary and lower secondary schools (Danish Ministry of Education, 2014a). Then, we present the empirical aspects of the study, including the methodology, data generation, findings and discussion. We close the article by describing challenges and implications for further research.

\section{Health and sustainability issues in Danish 'folkeskole'}

In Denmark, education is compulsory for all children aged 6-16 years. Provided that the national educational standards are met, parents can choose whether their children are educated in public primary and lower secondary schools (folkeskole), in private schools or at home. In other words, education, but not schooling, is compulsory. Nevertheless, approximately $81 \%$ of the children in Denmark attend public school, $16 \%$ attend private schools (frie skoler) and the rest (3\%) are schooled at home (Danish Ministry of Education, 2015a). The discussion in this article concerns the public schools governed by local authorities (municipalities) within the national educational law and curriculum framework (Danish Ministry of Education, 2013, 2014a).

Municipalities are responsible for overseeing the schools; municipal boards determine the schools'financial structure, set local goals, supervise the schools and monitor academic attainment and other results according to the national framework. Each school has a school board of representatives that includes parents, school staff and pupils; other local stakeholders may also be involved in the school board. The specifics can vary depending on, e.g., the size of the school and the municipality. The principal is responsible for the school's administration and pedagogy within the national and municipal guidelines. The principal 'responds' to the school board and to the municipal board. In practice, schools usually have a leadership team that consists of an administrative leader, a pedagogical leader and the heads of different departments based on the grade level.

Health education and education for sustainable development are transversal themes to be integrated across the boundaries of subject and grade. National goals and learning objectives have been drawn up for both themes and have been implemented either in theme-specific or general curriculum guidelines. In August 2014, the Danish Government initiated a comprehensive reform of primary and lower secondary education. Although the reform is primarily focused on academic attainment within core subjects (e.g. mathematics, science and Danish), health and well-being are also emphasized in the reform documents and related political agreements (Danish Ministry of Education, 2014a, 2014c). Sustainability education, however, is much less prominently addressed; although sustainability was clearly specified as one of the transversal issues in the former curriculum guidelines (Danish Ministry of Education, 2009) and was still visible in the initial drafts of the reform, it 'disappeared' when 
a broad political agreement about the reform was reached among the political parties in the Parliament (Madsen et al., 2015).

Since before the current reform, what has been positive about health education is that although it is not a separate subject, national curriculum guidelines for health education have been developed. The newly revised national curriculum guidelines describe the main objective of 'Health, Sexuality and Family Education' as follows:

[...] Pupils should gain knowledge and skills and develop competences to promote health and well-being for themselves and others. [...] Teaching should contribute to the development of pupils' engagement, will and courage to build bridges between knowledge and action related to health and well-being in everyday life. Central to the teaching process is dialogue with pupils concerning desire, quality of life, values and norms, rights, responsibilities and possible actions.

(Danish Ministry of Education, 2014d, p. 3)

This passage places health education within a critical health education approach within the paradigm of health-promoting schools (e.g. Clift \& Bruun Jensen, 2005; Green \& Tones, 2010; McNamara \& Simovska, 2015). It stresses the importance of pupils' ability to act to promote health and well-being, whether individually or as part of a community; the focus is on pupils' competence development and agency in support of health and well-being rather than on behaviour regulation and socialization that dictate predetermined healthy lifestyles. Furthermore, the excerpt from the curriculum guidelines above signifies a positive view of health: well-being and health are given equal billing, and the positive aspects of health such as desires and quality of life, rather than solely risks - are affirmed. Finally, the excerpt highlights the socio-ecological approach, including social determinants of health; this is visible in its emphasis on rights, responsibilities and possible actions beyond an individual level. The curriculum guidelines also suggest participatory teaching and learning methods and a high degree of pupil involvement are key pedagogical principles (ibid.) which are principles also endorsed by the health-promoting schools' initiative; research related to the initiative demonstrates the positive effects of pupils' participation in school-based health promotion in terms of both health and education outcomes (e.g. de Róiste, Kelly, Molcho, Gavin, \& Gabhainn, 2012; Griebler \& Nowak, 2012; Griebler, Rojatz, Simovska, \& Foster, 2014; Simovska, 2013).

Additionally, in relation to health and well-being, the school reform introduces $45 \mathrm{~min}$ of daily physical activity for all pupils and names the promotion of pupils' well-being among the key objectives (Danish Ministry of Education, 2013). It also underlines the importance of the whole school as an inclusive learning environment for all pupils.

Although the emphasis on health and well-being in school reform is open to interpretation, it could be viewed as placing a renewed importance on health education and on broader cross-disciplinary themes, participatory pedagogies and whole-school development related to health promotion, as suggested within the health-promoting schools' paradigm (Buijs, 2009; CBO, 2013). The reform might encourage pedagogies to focus on pupils' involvement,'real-world' action orientation related to health and collaboration between the school and stakeholders from the community surrounding the school.

Unlike health education, education for sustainability does not have a separate curriculum and teacher guidelines; environmental and sustainability education is incorporated into the curricula for a number of subjects, including nature and technology, social studies, history, geography, food literacy, fine art and design and craft. In each case, learning objectives related to sustainability and the environment are formulated and aligned with the overall 
aims of the respective subject. For instance, the aims described in the curriculum guidelines for social studies read as follows:

Students should gain an understanding of innovation as a prerequisite for economic growth and sustainability, and therefore, they should be able to explain the links between innovation, economic growth and sustainability. (Danish Ministry of Education, 2014b, Curriculum for Social Studies, p. 6)

As the excerpt shows, sustainability is linked with innovation and economic concerns. It is interesting to note that the aims for social studies do not include the social and cultural dimensions of sustainability, as the United Nations' definition suggests (United Nations, 2008). Moreover, social studies consist of three sub-topics - economics, politics and social and cultural issues - and sustainability is only addressed in economics lessons.

The wider dimensions of sustainability are more visible in the geography curriculum. The aims for this subject include pupils' ability to

Evaluate and discuss options for the development of economic, ecological and cultural sustainability. [...] Students should work with interests and conflicts of interest in the use of natural resources. This includes, among other things, different and conflicting views on nature, conservation, restoration, planning and interest groups. (Danish Ministry of Education, 2014b, Curriculum for Geography, p. 9)

The excerpt mentions the economic, cultural and environmental dimensions and echoes the UN's definition of sustainability. Similar indications of a more nuanced notion of sustainability are apparent in the goals for biology and food literacy.

The transversal thematic area 'innovation and entrepreneurship', which is new to the national curriculum, also addresses sustainability. This thematic area consists of four overall dimensions - action, creativity, understanding the outside world and personal orientation - and is highly visible across all subjects. However, sustainability education within this thematic area focuses primarily on goals linked to competitiveness and economic reasoning in the context of globalization.

Thus, it can be argued that although sustainability seemed to be'lost' as a distinct thematic area and in the general aims of schooling of the political agreement related to the reform (Danish Ministry of Education, 2013), sustainability did secure a foothold in the existing curricula for a number of subjects, if in a somewhat hidden form. It was predominantly framed in a narrow technical sense through endeavours that focus on the environment and climate change and economic growth rather than on the notions of social, cultural and economic sustainability and the development of pupils' agency in that respect. In contrast to the health education curriculum guidelines, which seem to be aligned with the critical educational research perspectives related to health, the critical educational ideas related to sustainability do not seem to fully emerge in the curriculum. This incomplete engagement occurred despite the political imperative established by the UN Decade of Education for Sustainable Development (United Nations, 2008) and despite scholarship in the area that consistently indicates the importance of engaging pupils with sustainability, developing their comprehensive and action-oriented competencies, motivation and agency, and doing so through participatory pedagogies, similar to the goals and methods set forth for health education (Gough, 2005; Henderson \& Tilbury, 2004; Jensen, Schnack, \& Simovska, 2000; Læssøe, Schnack, Breiting, \& Rolls, 2009; Reid et al., 2008; Young, 2015). Arguably, the barely visible position of sustainability education in the curricula creates limited room for practice. For both thematic areas, research has shown that Danish school teachers and other school 
stakeholders convey uncertainty about the meaning of the concept of sustainable development and about health that focuses on global social issues in a broad sense rather than on behaviour regulation, and they are uncertain about appropriate teaching strategies for these complex themes (Madsen, 2013; Nordin, 2013; Smidt, 2012).

\section{School leadership and health and sustainability education}

The school reform frames school leadership using seven fields or action areas (Danish Ministry of Education, 2015b), including (a) the leadership of the open school, (b) the leadership of subject teaching and cross-professional collaboration, (c) the leadership of capacity building and professional development, (d) the leadership of learning environments, (e) the leadership of strategy and change processes, (f) the leadership of well-being, motivation and engagement and ( $g$ ) the leadership of knowledge and results-based teaching development. These action areas indicate the school principals' responsibility in terms of school development, the professional development of staff and cross-subject pedagogical practices for ensuring the well-being, motivation and engagement of all members of the school community, including pupils. Finally, the school leadership is also accountable for results-based teaching. This represents a major change that the reform introduces to Danish schools, which were previously governed by broad democratic educational aims, values and content (Moos, 2014) that emphasized strategy rather than administration and instruction (Pors \& Staunæs, 2011).

In principle, the leadership fields outlined above could be viewed as potentially conducive to health and sustainability pedagogy because both themes require whole-school, multidisciplinary and participatory approaches and assume that the school engages with its surrounding community and works with real-world problems (Madsen et al., 2015). As mentioned above, research has indicated school principals' important role in initiating, implementing and sustaining health and sustainability education efforts across the curriculum and integrating them into the school organization and culture. An interesting issue, then, is how school principals prioritize, appropriate and transform these leadership action areas in the real world of messy school practices.

It is important to note that the school leadership document developed as a part of the reform (Danish Ministry of Education, 2015b) refers to school'leadership'rather than a school 'principal'; furthermore, each leadership field is operationalized in connection to the school level and the municipal administrative level. In line with Pors (2014), this type of school governance can be seen as simultaneously decentralized and centralized because it blurs the boundaries of responsibilities and room for decision-making while simultaneously increasing the school principals' accountability in terms of 'results'.

In previous research (Simovska, Nordin, \& Madsen, 2015), we have focused on municipal stakeholders' perspectives regarding health and sustainability education in schools. In this paper, we turn the spotlight on school principals' perspectives on these cross-curricular thematic areas.

\section{Study design}

The empirical data were generated through an online survey of school principals in Denmark $(n=118)$ administered in May 2014. The web programme Surveyxact was used 
to develop the survey and gather the data. The survey was sent to 254 principals who were randomly selected from the principals of all 1376 primary and lower secondary schools (Local Government Denmark, 2013). A total of 118 school principals responded, with a $46 \%$ response rate. Although this rate was lower than expected, the responses are representative in terms of geography and school size, as quantified by a chi-square test ( $p>0.5$ for both specified proportions).

The survey was structured into three main sections: (a) background information, (b) questions concerning health issues and (c) questions concerning sustainability issues. The background information included the principals' gender, age and number of years in the position, the schools' size and the pupils' ages. The questions about health and sustainability education explored the school principals' views on the following topics: the general schoolwork, the formalization and prioritization of the two topics at the school level, teachers' professional development, internal collaboration (within the school), external collaboration (the school with municipalities and other stakeholders, e.g. NGOs, the private sector and universities) and the opportunities and barriers arising from the new school reform.

The school principals were initially contacted with a letter that provided information about the aims and purpose of the study, the ethics, the method and the amount time that the survey was expected to take them to complete. After they provided their consent, they were sent a link to the survey in an email that emphasized the principles of anonymity, confidentiality and the right to withdraw from the study. Reminders were provided, and follow-up contact was made by telephone and/or email over the four-week period.

Data management comprised calculating the percentages of participants that gave a given response to each question. Guided by the research questions and conceptual perspectives discussed above, the analysis looked for convergences, tensions and contradictions that emerged from a consideration of the survey responses as a whole.

\section{Findings}

We present the findings related to both health and sustainability together, and we discuss convergences and divergences in the school principals' perspectives on the two themes and the contradictions and tensions within each theme.

\section{School has an important role to play, but}

Figures 1 and 2 present the responses related to two issues: (1) the importance of the school for developing pupils' competencies related to health and sustainability and (2) health and sustainability as focus areas within the school's practice.

The findings show that in general, the principals perceive schools as important for pupils' education in both health and sustainability (Figure 1). All of the respondents state that school is very important $(79 \%)$ or important $(21 \%)$ in terms of health education, and the responses regarding sustainability education were similar (63 and 35\%, respectively). There was a slight difference in the perceived importance of the school for health education and sustainability; $2 \%$ of respondents state that school is not important for sustainability education, whereas none of the respondents state the same about health education. 


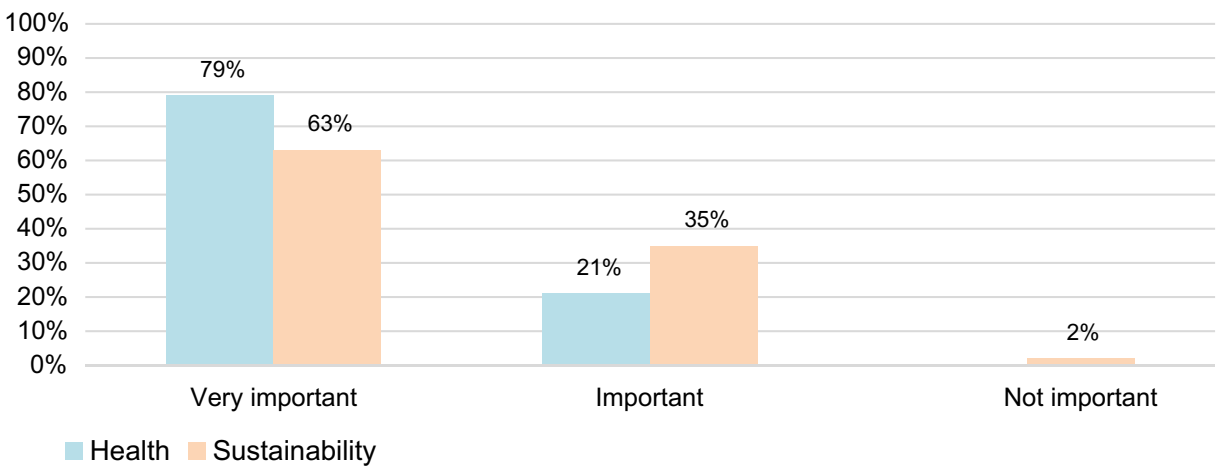

Figure 1. Importance of school for health and sustainability education.

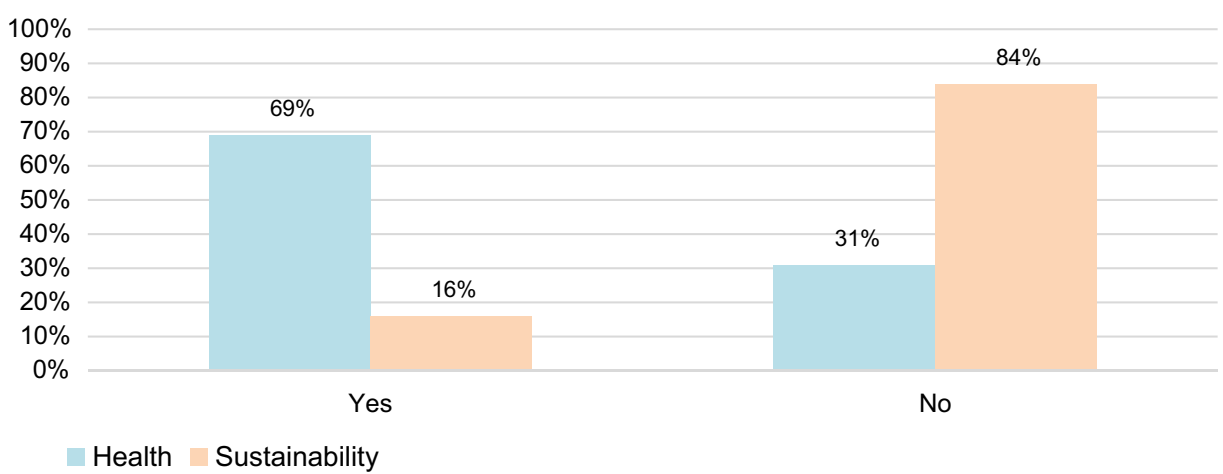

Figure 2. Focus on health and sustainability in practice.

This difference increases considerably in the responses to the question about health and sustainability as an actual focus of teaching (Figure 2). While $69 \%$ of the respondents report that health is a focus area at their school, only $16 \%$ state that sustainability is a focus area.

The findings show that the difference between the number of school principals who consider schools important for health education (79\%) and those who report health as a teaching focus area at their school (69\%) is not large. In contrast, while $63 \%$ of the school principals perceive school as important for sustainability education, only $16 \%$ report that sustainability is an actual area of focus in the school's pedagogical work. These results indicate a discontinuity between school principals' intentions and their actual prioritization of sustainability education.

\section{The curriculum aims are mandatory, but ...}

Figure 3 presents the school principals' responses to the question about the formal curricula related to health and sustainability issues. As mentioned, although the national aims are mandatory, schools can develop their own local curriculum guidelines and syllabi for cross-curricular and cross-disciplinary topic areas, such as health and sustainability. The findings demonstrate substantial differences between approaches to health education and approaches to sustainability education. Regarding health education, $51 \%$ of the school 
principals state that their schools follow the national curriculum guidelines for'health, sexuality and family education', and 28\% state that their schools have developed local guidelines for health education. For sustainability education, only $17 \%$ of the school principals report that their schools follow national curriculum guidelines, $18 \%$ report that they have developed local guidelines and the large majority (65\%) report that they are not certain.

Regarding health education, half of the school principals state that their schools follow the national curriculum guidelines, and nearly one-third report having a locally developed curriculum. Regarding sustainability, most of the school principals are uncertain about the status of the formal curricula. Among the school principals who are aware of the formal aims, the percentage that reports following locally developed curriculum guidelines is nearly the same as the percentage that reports following the national curriculum aims. The relatively high percentage (18\%) who reported using locally developed curricula for sustainability education may indicate that when sustainability is placed on the agenda, schools develop their own aims and guidelines.

\section{Teachers' professional development is not a high priority}

The above-mentioned differences between the prioritization of health and sustainability education are also reflected in the principals' prioritization of teachers' professional development in those areas (Figure 4).

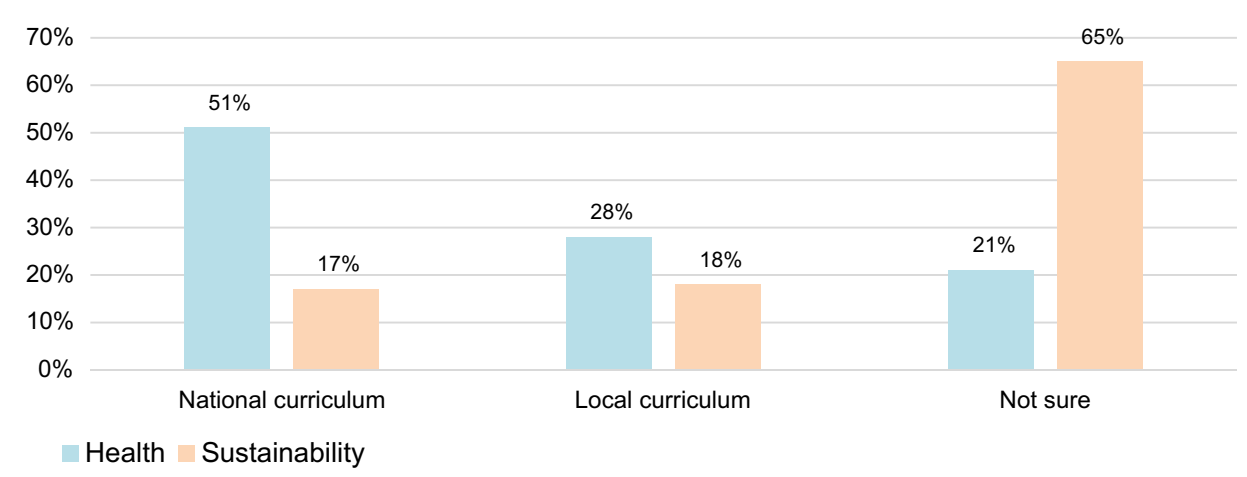

Figure 3. Curriculum aims followed.

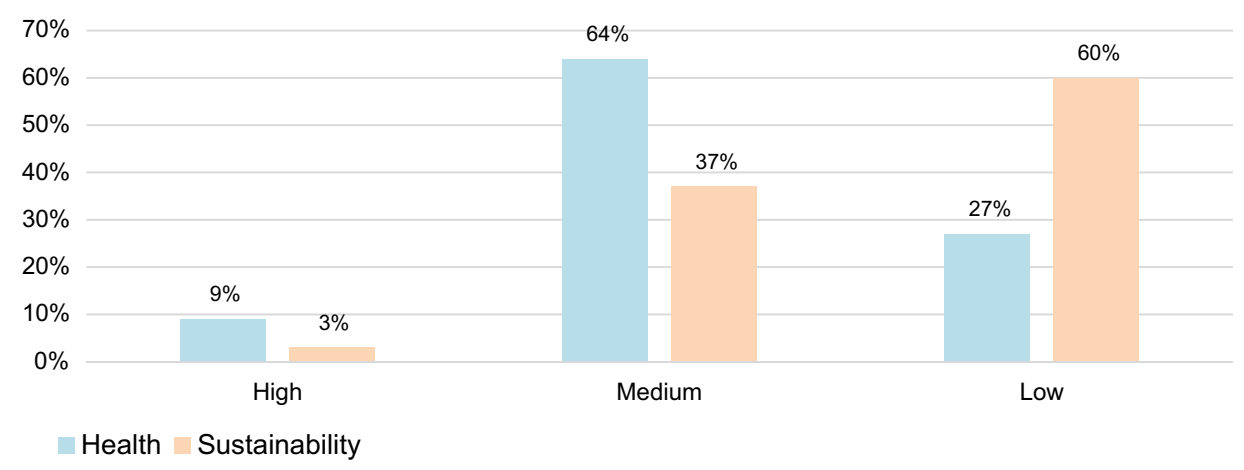

Figure 4. Priority to teacher professional development. 


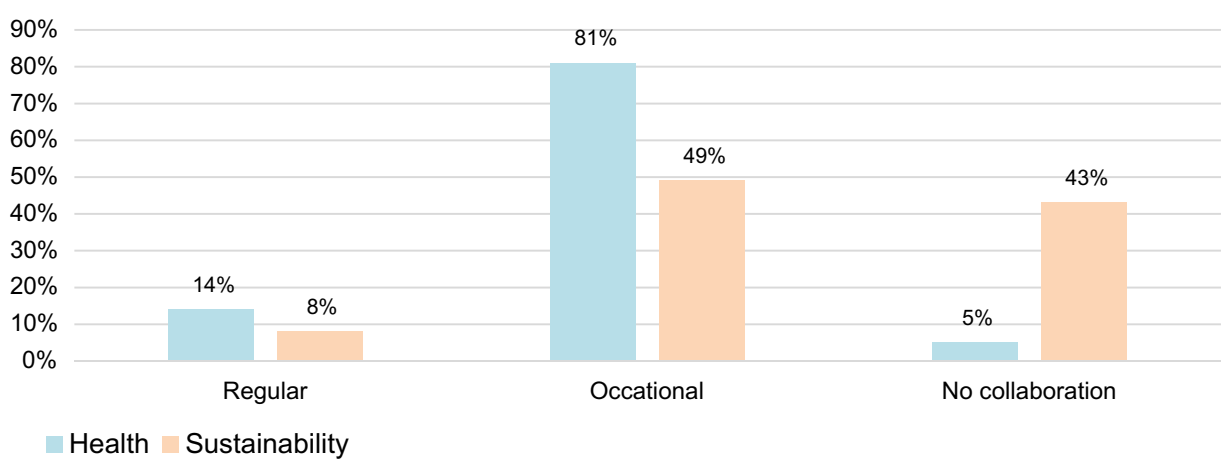

Figure 5. Priority to collaboration with teachers.

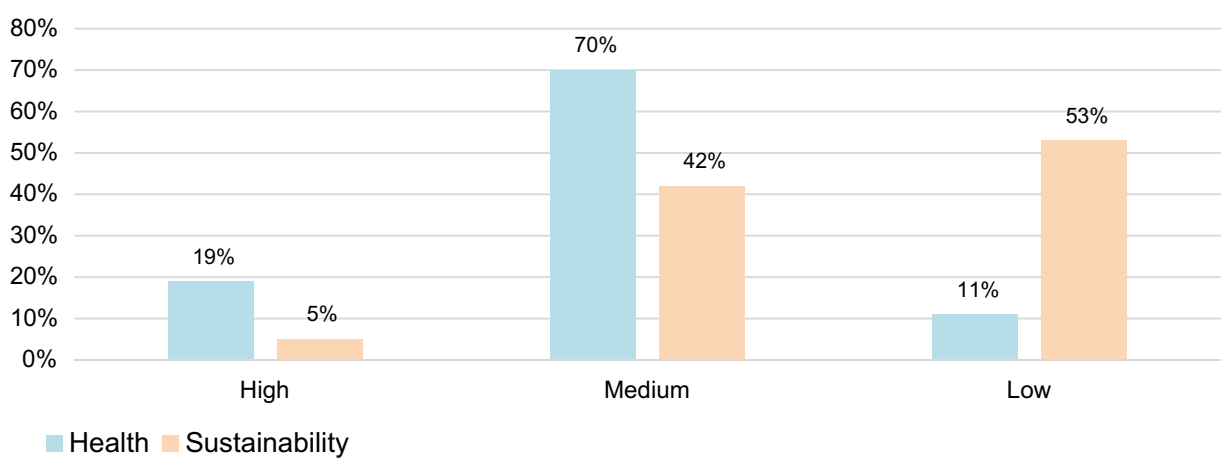

Figure 6. Priority to interdisciplinary collaboration between teachers.

While majority (64\%) of the principals state that they give medium priority to teachers' professional development in health education, the majority (60\%) explicitly state that they do not prioritize teachers' professional development in sustainability education; $9 \%$ of the principals state that they give high priority to teachers' professional development for health education, but only $3 \%$ state the same for sustainability education. In addition to the differences between the two thematic areas, the findings indicate a relatively low prioritization of teachers' professional development in those areas.

\section{Limited internal collaboration}

The following two figures present the school principals' responses related to the collaboration within the school concerning health and sustainability education. Figure 5 presents the responses regarding collaboration between the school principals and teachers. Figure 6 presents the school principals' responses regarding the prioritization of cross-disciplinary collaboration among teachers of different subjects.

As Figure 5 shows, regarding health education, $81 \%$ of the school principals report sporadic collaboration, $14 \%$ report close collaboration and $5 \%$ report no collaboration with teachers. For sustainability, the principals report little collaboration with teachers. Only $8 \%$ of 


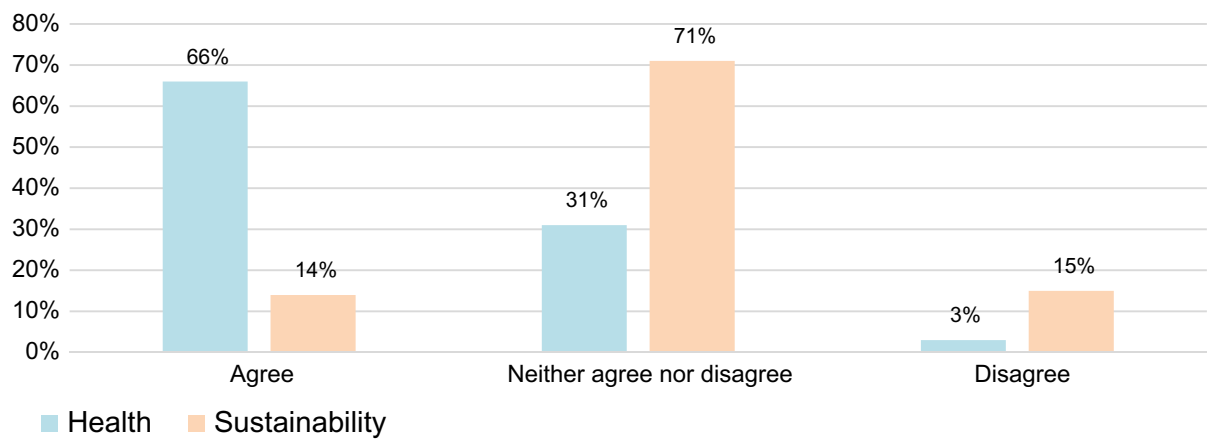

Figure 7. Collaboration with the municipality characterized as good.

the respondents report close collaboration with teachers, $49 \%$ report sporadic collaboration and $43 \%$ report no collaboration at all.

Figure 6 illustrates the priority that school principals give to teachers' interdisciplinary collaboration in relation to health and sustainability education. It is important to note that in the Danish school context, teachers have autonomy to plan their subject curricula. The reform, however, places responsibility on school principals to encourage cross-curricular collaboration and teamwork between teachers of different subjects. This particularly applies for the topics which are integrated in the subjects, such as health and sustainability.

The findings favour health education in a manner similar to the results reported above: $70 \%$ of the school principals state that they prioritize cross-subject collaboration among teachers to some degree, $19 \%$ report a high degree of prioritization and $11 \%$ do not give priority to such collaboration. In contrast, for sustainability, more than half of the school principals (53\%) do not give priority to cross-subject collaboration, $42 \%$ give it some priority and only $5 \%$ report giving it high priority.

Thus, although the findings demonstrate some collaboration between school principals and teachers regarding health education, it is fair to say for both thematic areas, the principals collaborate with teachers only minimally. Additionally, the findings show that health education is clearly prioritized as a cross-disciplinary thematic area that requires collaboration among teachers in different subjects, while the same does not seem to be true for sustainability.

\section{Limited external collaboration}

Figures 7 and 8 present the responses related to the collaboration between the school and the local community on health and sustainability education. Figure 7 focuses on the school principals' assessment of the quality of the collaboration between the school and the municipality.

Consistent with the previous findings, the differences in collaboration for health and for sustainability are clear; for health education, $66 \%$ of the school principals describe the collaboration with the municipality as good, $3 \%$ describe it as not good and $31 \%$ do not take a stance. In contrast, for sustainability, only $14 \%$ of the school principals characterize the collaboration with the municipality as good, $15 \%$ state that it is not good and $71 \%$ do not state an opinion. 


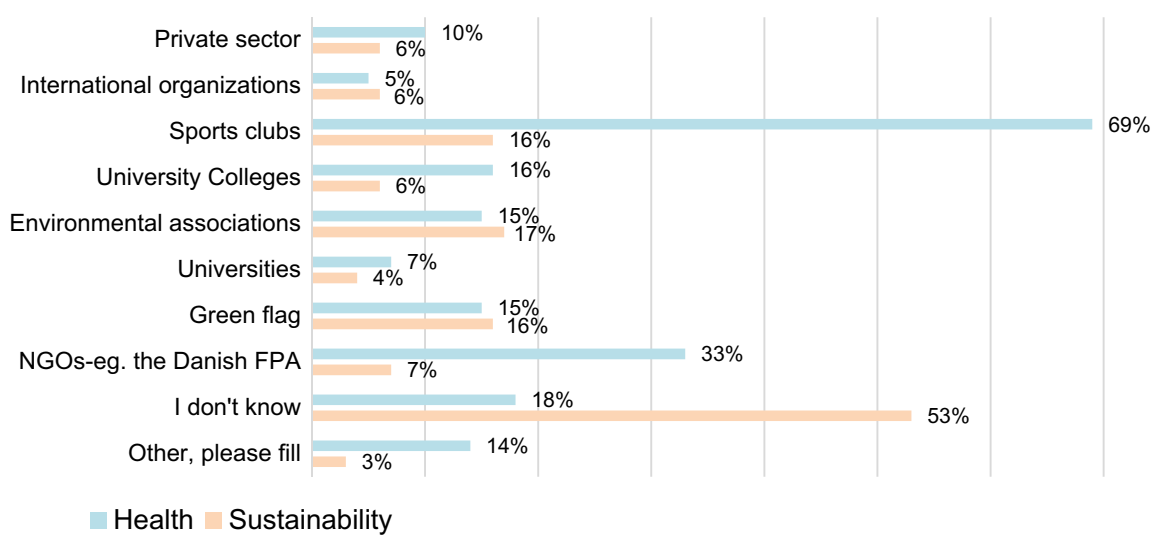

Figure 8. Relevant local stakeholders.

Figure 8 shows which stakeholders in the local community the school principals name as collaboration partners for health and sustainability education. For health education, the most frequently reported external collaboration partner is sports clubs (69\%), followed by NGOs (33\%); $18 \%$ of the responses are 'do not know'. In the open category 'others', the respondents mention school nurses, medical doctors, psychologists, the local government, parents, private individuals, retired local people who act as volunteers, local councils, kindergartens, nature guides and shelters. For sustainability, more than half of the school principals (53\%) report that there is no collaboration with the local community. Among the mentioned external collaborators, sports clubs are mentioned again, although at a lower rate than for health education (16\%). The other local stakeholders mentioned are different types of local environmental organizations.

In general, the findings show that from the school principals' perspectives, collaboration with local authorities and other stakeholders is considerably better for health education than for sustainability education, and sports organizations are perceived as the most obvious collaboration partner.

\section{Summary and discussion}

The survey results indicate that although the school principals clearly see the school as an important arena for both health education and sustainability education, their actual support of related school practices lags behind. The school principals seem to make health education a substantially higher priority than sustainable development education. This finding could be explained by the fact that health education has its own national curriculum guidelines, whereas sustainability is integrated into a number of subjects. The integrated approach to sustainability education makes it more abstract and difficult to integrate into leadership work, particularly in the context of the ongoing school reform, which places many demands on principals, including some that are contradictory. The higher prioritization of health education may also be the result of municipal- and national-level pressure that the health sector puts on schools to address health problems, for example, overweight and obesity among school-aged children. In contrast, although sustainability assumes a relatively high position on the global, national and local political agenda, it is arguably considered more a matter of 
technical solutions and economics than an issue that could or should be addressed through education.

It is fair to emphasize here that there are factors contributing to the explanation of the findings, which transcend the hegemonic power of policy or curriculum guidelines or the reform. These factors are beyond the scope of this study, but are nevertheless worth acknowledging as they refer to the broader context influencing the practice of school principals in this respect. For example, the level of autonomy and administrative control of principals, or wider community and/or school factors (e.g. demographic, socio-economic, cultural and other characteristics of teachers, pupils and parents) could be relevant to consider. Leadership as professional practice is also contingent upon individual features of principals shaped by the interaction between contextual or structural framings, on the one side, and personal and professional histories, subjectivities, values, desires, imagination and decision-making capacities, on the other.

For both thematic areas, the study reveals a discrepancy between the principals' views on the importance of the school for addressing the issues and the actual practice of doing so. The discrepancy is larger for sustainable development education than for health education. These findings are consistent with the literature; a similar discrepancy between what schools claim about the importance of sustainability education and what they report actually doing in practice was identified by Jackson (2007). Similarly, a study by Kadji and colleagues showed that school principals convey intentions to support schoolwork related to sustainability but are not willing to commit to initiate substantial changes, among other things, due to lack of professional development for principals (Kadji-Beltran, Zachariou, \& Stevenson, 2013). Additionally, Zachariou and Kadji-Beltran (2009) and Madsen (2013) have demonstrated that most school principals and teachers only vaguely comprehend the concept of sustainable schools. Discrepancies between intentions, ideals and values, on the one hand, and the realities of practice, on the other, have also been reported in the literature on health education and health-promoting schools (e.g. Nordin, in press; Samdal \& Rowling, 2015; Simovska, 2004).

The findings show that the curriculum aims linked to health are more evident in perceived leadership areas than the aims linked to sustainability. This is likely because national curriculum guidelines exist for health, sexuality and family education, which makes the thematic area a more distinct field of leadership attention. Although sustainability is included in the aims of a number of subjects and in the transversal theme 'innovation and entrepreneurship', it does not seem to attract the attention of school principals. Other research in Denmark (Danish Evaluation Institute, 2012) also showed that despite being aware of the legally binding nature of the national curriculum aims, school principals perceive them more as guiding principles and are confident that teachers are including them in their teaching. In other words, following up on the actualization of the curriculum aims is not something the principals allocate high priority to in their leadership tasks. This is in contrast to research that suggests that one of the important features that distinguishes 'good' school principals is taking responsibility for achieving the curriculum's aims and promoting related pedagogical practices (Törnsén, 2009). Research on both sustainability and health education emphasizes that whole-school approaches, or what Jackson (2009) calls the 'living curriculum', can be a supporting factor in transversal thematic areas if they help to achieve the curriculum's aims, rather than adding on to them (Gough, 2005; Henderson \& Tilbury, 2004). Evidently, school principals have an important role to play in that respect by integrating health and 
sustainability into the visions and the culture of the school in ways that facilitate and follow up on the actualization of the aims within and across the curriculum subjects.

The study also demonstrates the insufficient priority that school principals give to teachers' professional development for working pedagogically with the issues of health and sustainability education and their insufficient support for cross-disciplinary work on the two thematic areas across the subjects in the curriculum. This finding is in contrast with the framing of the two thematic areas in the national curriculum guidelines. Also, research clearly emphasizes the importance of teachers' competencies and continuous professional development for both thematic areas (e.g. Hargreaves, 2013; International Union for Health Promotion and Education [IUHPE], 2009; Jourdan, 2011; Whitman, 2005). Further, Deschesnes, Drouin, Tessier and Couturier (2014) specifically indicate the importance of school principals' support in developing teachers' competencies to work pedagogically with unpredictable issues with complex contexts, such as health and well-being. Additionally, the literature suggests that the professional development of both teachers and school principals is important for both health and sustainability education (Dadaczynski \& Paulus, 2015; Larsen \& Samdal, 2008; Kadji-Beltran et al., 2013).

In a similar vein, the findings reveal limited internal interactions between school principals and teachers and among teachers and a lack of external collaboration between the school and local community stakeholders for both health and sustainability education. Consistent with the previous findings, both internal and external collaboration is somewhat better for health education than for sustainability education. In the case of health education, the school principals report that some collaboration exists, but collaboration is very limited or non-existent in the case of sustainability education. These findings are in contrast to recommendations based on research. For example, Leo and Wickenberg (2013) suggest that clear expectations between principals and teachers are necessary to support professional norms conducive to implementing sustainable development education. Scott (2013), building on the previous research within environmental education differentiating between education 'about','for' and 'in' the environment, (see, e.g. Linke, 1979), has emphasized the importance of the school principal in building personal and social capacities at schools and reorienting the school ethos towards learning as sustainability rather than for sustainability through collaboration with teachers. This emphasis is supported in the field of health education by Jourdan (2011), who argues that cross-disciplinary topic areas demand the involvement of not only teachers, but the entire school staff, including school principals, and whole-school development is necessary. In this respect, Larsen and Samdal (2008) have suggested that two complementary guidelines - one for teachers and one for school leadership - should support the implementation of a health promotion programme. The guidelines for school leaders should focus on ways to provide support for key individuals at school and to create supportive structures related to the thematic area. In support of this, Dadaczynski and Paulus (2015) suggest that health promotion in schools should also include supporting school principals so that they can support their schools' health education work. However, research has also suggested that too much structure may hinder collaboration, particularly for cross-subject thematic areas and whole-school approaches (Henderson \& Tilbury, 2004). Thus, although research indicates the importance of supportive structures and collaboration between teachers and school principals, there is no one simple way in which school principals can address this need.

The picture is similar for collaboration between the school and the local community. The Danish school reform explicitly states that the school should be 'open' and collaborate with 
the surrounding community and that school principals play a crucial role in establishing and sustaining this collaboration. Symons (2008) emphasized the importance of strong links between the school and the wider community, including local businesses, particularly in terms of the development of participatory teaching and decision-making structures. The literature on health-promoting schools clearly underlines the importance of partnerships between schools and communities for the successful implementation and sustainability and the role school principals play in establishing these partnerships (Inchley et al., 2006; Samdal \& Rowling, 2013, 2015). Our study found that the school principals somewhat prioritize the collaboration between schools and local stakeholders in the case of health education, but collaboration is almost non-existent for sustainable development education. Clearly, there is room for improvement in this respect. However, the findings are not surprising, given the large number of new demands that the school principals face within the context of the ongoing school reform in Denmark. Often, these demands are mutually contradictory; sometimes, they clash with the culture and norms that had characterized school leadership in Danish schools for decades prior to the reform, for example, the culture valuing distributed leadership and high level of teacher autonomy and focus on wider educational aims and ideals linked to democracy. Such contradictions further complicate school principals' work, as Pors and Staunæs (2011) and Pors (2014) show.

\section{Concluding reflections}

It is not the task of schools to solve societal problems. However, within the logic of critical perspectives on education, educational work with key societal issues (Klafki, 2005), including health and sustainability (Schnack, 2000, 2008), does belong within the domains of schooling. Moreover, if the purpose of education is more than formal qualification and socialization (Biesta, 2006, 2013) and also includes'rupture in the order of things' (Ranciére cited in Biesta, 2013 , p. 84) to allow space for subjectification, real-world oriented aims and participatory pedagogies, i.e. those related to health and sustainability education and discussed in this paper, are worth considering.

Both concepts and the related societal challenges are contingent, contested and based on uncertain knowledge. Thus, the sole purpose of education cannot be for pupils to acquire predetermined sets of knowledge and skills to address current and future problems or to become socialized to adopt particular ways of being. Rather, the purpose needs to be understood in terms of creating educational spaces and relationships in which pupils can critically and imaginatively explore, reflect and relate to these issues, create meaning and search for solutions in their own unique ways while confronted with a plurality of meanings. This demands a different approach to curricula that transcends disciplines and subjects and aims at more than measurable outcomes in terms of prescribed knowledge, skills and attitudes.

Health and sustainability education, as discussed in this article, call for whole-school development; that is, the development of a dynamic interplay of the curriculum's aims, cross-curricular thematic areas, the physical and psycho-social environment of the school and partnerships between the school and the local community. In other words, education in these thematic areas calls for the development of a school-wide ethos or culture in which the curriculum can be understood as a 'space of emergence' (Osberg \& Biesta, 2008) rather than predetermined enculturation that, in the case of health and sustainability education, would imply focusing on behaviour regulation to promote'healthy' or'sustainable' lifestyles. 
Undoubtedly, this perspective assumes a new view of education in general and of health and sustainability education in particular. In this paper, we have acknowledged that school principals have an important role to play and that school leadership matters. Nonetheless, in times of school reforms based on different, often conflicting educational principles and approaches, the issue is how much room school principals truly have to facilitate and lead these school and curricular development processes. The challenge then is not how school principals can or should support the 'implementation' of the curricular aims related to global social issues in schools, but how ideas about school leadership can reconnect with ideas about the wider purposes of education, curriculum and schooling. Further research into principals' and perhaps also teachers' agency could be one beneficial line of research to inform inquiries relating to global social challenges in the curriculum; exploring how professional and personal histories of principals, their projective imaginations of solutions to educational challenges and professional judgement of the possibilities that a particular moment in a particular context affords for bringing about change (Emirbayer \& Mische, 1998) could help understand the intertwined character of agency, which is contingent on structures and context and at the same time shapes them. This, in turn would allow for a more nuanced dialogue on educational reforms, potentialities and constraints of the curriculum and possibilities for change.

\section{Disclosure statement}

No potential conflict of interest was reported by the authors.

\section{Funding}

This work was supported by Aarhus University Research Foundation through the AU IDEAS PILOT CENTRES scheme, granted for the period 2012-2016. The AU IDEAS funding scheme aims to support visionary and innovative interdisciplinary research ideas over a period of 5 years.

\section{Notes on contributors}

Venka Simovska is a professor and leader of the 'Research Programme on Learning for Care, Sustainability and Health' at the Department of Education, Aarhus University, Denmark. Tuborgvej 164. 2400 Copenhagen NV. Denmark. vs@edu.au.dk. 0045871635 89. Simovska also leads the 'Research Centre on Schools for Health and Sustainability' at the Department. Simovska has authored and co-authored a number of books, book chapters and journal articles in the fields of health education and health-promoting schools. Most recently, she has edited, together with McNamara, P. (2015), Schools for Health and Sustainability, Dordrecht, Springer.

Åsa Kremer Prøsch holds an MA in Educational Sociology, and is currently working as a research assistant in the 'Research Centre on Schools for Health and Sustainability' at the Department of Education, Aarhus University. Her research interests include curriculum interpretation and transformation concerning health and sustainability education.

\section{References}

Biesta, G. (2013). The beautiful risk of education. Boulder, CO: Paradigm Publishers.

Biesta, G. J. J. (2006). Beyond learning: Democratic education for a human future. Boulder, CO: Paradigm Publishers.

Buijs, G. M. (2009). Better schools through health: Networking for health promoting schools in Europe. European Journal of Education, 44, 507-520. 
CBO. (2013). State of the art. Health promoting schools in Europe. Retrieved August 29, 2014, from http:// www.schools-for-health.eu/uploads/files/SHE-Factsheet_1_State_of_art_Health\%20Promoting\%20 Schools.pdf

Cheng, Y. C. (2002). The changing context of school leadership: Implications for paradigm shift. In K. Leithwood \& P. Hallinger (Eds.), Second international handbook of educational leadership and administration (pp. 103-132). London: Kluver Academic Publishers.

Cheng, Y. C. (2011). Towards the 3rd wave of school leadership. Revista de Investigación Educativa, 29, 253-275.

Clift, S., \& Bruun Jensen, B. (2005). The health promoting school: International advances in theory, evaluation and practice. Copenhagen: Danish University of Education Press. Retrieved February 24, 2015, from http://www.euro.who.int/_data/assets/pdf_file/0012/111117/E90358.pdf

Dadaczynski, K., \& Paulus, P. (2015). Healthy principals - Healthy schools? A neglected perspective to school health promotion. In V. Simovska \& P. M. McNamara (Eds.), Schools for health and sustainability - Theory, research and practice (pp. 253-273). London: Springer.

Danish Evaluation Institute. (2012). Fælles mål i folkeskolen. En undersøgelse af lærernes brug af fælles mål [Common aims. An investigation of the teachers use of common aims]. Danish Evaluating Institute, Copenhagen. Retrieved February 24, 2015, from http://www.eva.dk/projekter/2012/laereres-brugaf-faelles-mal/projektprodukter/faelles-mal-i-folkeskolen/view?searchterm=fælles\%20mål\%20i\%20 folkeskolen

Danish Ministry of Education. (2009). Fælles mål: Sundheds - og seksualundervisning og familiekundskab [National curriculum: health, sexuality and family education]. Retrieved January 10, 2015, from http:// www.uvm.dk/Service/Publikationer/Publikationer/Folkeskolen/2009/Faelles-Maal-2009-Sundhedsog-seksualundervisning-og-familiekundskab

Danish Ministry of Education. (2013). Folkeskoleloven pr. 1. August 2014 [Reform of act for primary and lower secondary school]. Retrieved March 3, 2015, from http://www.uvm.dk/Den-nye-folkeskole/ Lovgrundlag

Danish Ministry of Education. (2014a). Nationale mål og enklere regler [National aims and simplified rules]. Retrieved December 15, 2014, from http://www.uvm.dk/Den-nye-folkeskole/Skoleledelseog-styring/Nationale-maal-og-enklere-regler

Danish Ministry of Education. (2014b). EMU - Danmarks læringsportal [Denmarks gateway for teaching]. Retrieved December 15, 2014, from http://www.emu.dk/omraade/gsk-lærer/

Danish Ministry of Education. (2014c). Trivsel og undervisningsmiljø [Wellbeing and the school environment]. Retrieved March 5, 2015, from http://www.uvm.dk/Den-nye-folkeskole/En-laengereog-mere-varieret-skoledag/Trivsel-og-undervisningsmiljoe

Danish Ministry of Education. (2014d). Fælles mål: Sundheds - og seksualundervisning og Familiekundskab [National curriculum: Health, sexuality and family education]. Retrieved December 15, 2014, from http://ffm.emu.dk/sites/default/files/unv_laeseplan_for_emnet_sundheds-_og_seksualunde rvisning_og_familiekundskab.pdf

Danish Ministry of Education. (2015a). Elevtal i folkeskolen og frie skoler [The number of pupils in public and private schools]. Retrieved September, 18, 2015, from http://www.uvm.dk/Service/Statistik/ Statistik-om-folkeskolen-og-frie-skoler/Statistik-om-elever-i-folkeskolen-og-frie-skoler/Elevtal-ifolkeskolen-og-frie-skoler

Danish Ministry of Education. (2015b). Den daglige skoleledelse [The everyday school leadership]. Retrieved February 22, 2015, from http://uvm.dk/Den-nye-folkeskole/Skoleledelse-og-styring/ Den-daglige-skoleledelse\#Publikationer

de Róiste, A., Kelly, C., Molcho, M., Gavin, A., \& Gabhainn, S. N. (2012). Is school participation good for children? Associations with health and wellbeing. Health Education, 112, 88-104.

Deschesnes, M., Drouin, N., Tessier, C., \& Couturier, Y. (2014). Schools' capacity to absorb a healthy school approach into their operations - Insights from a realist evaluation. Health Education, 114, 208-224.

Emirbayer M., \& Mische A. (1998). What is agency? The American Journal of Sociology, 103, 962-1023.

Gough, A. (2005). Sustainable schools: Renovating educational processes. Applied Environmental Education \& Communication, 4, 339-351.

Green, J., \& Tones, K. (2010). Health promotion, planning and strategies (2nd ed.). London: SAGE.

Griebler, U., \& Nowak, P. (2012). Student councils: A tool for health promoting schools? Characteristics and effects. Health Education, 112, 105-132. 
Griebler, U., Rojatz, D., Simovska, V., \& Foster, R. (2014). Effects of student participation in school health promotion: a systematic review. Health Promotion International, 4-12, doi:10.1093/heapro/dat090

Hallinger, P. (2010). Leading educational change: Reflections on the practice of instructional and transformational leadership. Cambridge Journal of Education, 33, 329-352.

Hargreaves, A. (2013). The perceived value of health education in schools: New Zealand secondary teachers' perceptions. Journal of Curriculum Studies, 45, 560-582.

Henderson, K., \& Tilbury, D. (2004). Whole-school approaches to sustainability: An international review of whole-school sustainability programs. Australian Research Institute in Education for Sustainability (ARIES) for The Department of the Environment and Heritage, Australian Government, Sydney. Retrieved November 5, 2014, from http://citeseerx.ist.psu.edu/viewdoc/ download?doi=10.1 1.231.7017\&rep=rep1\&type $=$ pdf

Inchley, J., Muldoon, J., \& Currie, C. (2006). Becoming a health promoting school: Evaluating the process of effective implementation in Scotland. Health Promotion International, 22, 65-71.

International Union for Health Promotion and Education. (2009). Achieving health promoting schools: Guidelines for promoting health in schools. Retrieved November 12, 2014, from http://www.iuhpe. org/images/PUBLICATIONS/THEMATIC/HPS/HPSGuidelines_ENG.pdf

Jackson, L. (2007). Leading sustainable schools. Nottingham: National College for School Leadership. Retrieved December 6, 2014, from http://www.arcworld.org/downloads/14669_lead_sus_school\%20 (2).pdf

Jackson, S. (2009). Enviroschools in New Zealand (MAI Review, 1, Intern Research Report 5). Retrieved December 4, 2015, from http://www.review.mai.ac.nz/index.php/MR/article/viewFile/212/227

Jensen, B., Schnack, K., \& Simovska, V. (Eds.). (2000). Critical environmental and health education: Research issues and challenges. Copenhagen: The Danish University of Education.

Jourdan, D. (2011). Health education in schools. The challenge of teacher training. Saint-Denis: Inpes, Coll. Santé en action.

Kadji-Beltran, C., Zachariou, A., \& Stevenson, R. B. (2013). Leading sustainable schools: Exploring the role of primary school principals. Environmental Education Research, 19, 202-323.

Klafki, W. (2005). Dannelsesteori og didaktik - nye studier [General education and Didaktik - New studies] (2nd ed.). Århus: Klim.

Læssøe, J., Schnack, K., Breiting, S., \& Rolls, S. (2009). Climate change and sustainable development: The response from Education. A cross-national report from international alliance of leading education institutes. Copenhagen, Department of Education, Aarhus University Press. Retrieved October 13, 2014, from http://edu.au.dk/fileadmin/www.dpu.dk/viden/temaeraaa/klimaogmiljoepaedagogik/ forskning_miljoe-og-sundhedspaedagogik_klimakonference-2009_20091210145447_dpu_rapport. pdf

Larsen, T., \& Samdal, O. (2008). Facilitating the implementation and sustainability of second step. Scandinavian Journal of Educational Research, 52, 187-204.

Leo, U., \& Wickenberg, P. (2013). Professional norms in school leadership: Change efforts in implementation of education for sustainable development. Journal of Educational Change, 14, 403-422.

Linke, R. D. (1979). Environmental education in Australia. Sydney: George Allen \& Unwin.

Local Government Denmark. (2013, April). Faktaark: Folkeskolen [Factsheet: Primary and lower secondary school]. Retrieved October 16, 2014, from http://www.kl.dk/Folkeskolen/FAKTA-OMFOLKESKOLEN-id83270/

Madsen, K. D. (2013). Unfolding education for sustainable development as didactic thinking and practice. Sustainability, 5, 3771-3782.

Madsen, K. D., Nordin, L. L., \& Simovska, V. (2015). Linking health education and sustainability education in schools: Local transformations of international policy. In V. Simovska \& P. M. McNamara (Eds.), Schools for health and sustainability. Theory, research and practice (pp. 81-109). Dordrecht: Springer.

McNamara, P. M., \& Simovska, V. (2015). Schools for health and sustainability: Insights from the past, present and for the future. In V. Simovska \& P. M. McNamara (Eds.), Schools for health and sustainability - Theory, research and practice (pp. 3-17). Dordrecht: Springer.

Moos, L. (2014). Educational governance in Denmark. Leadership and Policy in Schools, 13, 424-443. 
Nordin, L. L. (2013). Fra politik til praksis: implementering af kommunale sundhedsfremmeprojekter med fokus på kost og fysisk aktivitet fra et lærerperspektiv [From policy to practice: implementation of municipal health promotion projects focusing on diet and physical activity - teachers' perspective] (Doctoral dissertation). Department of Education, University of Aarhus, Copenhagen.

Nordin, L. L. (in press). Implementing the health promoting school in Denmark: A case study. Health Education.

Osberg, D., \& Biesta, G. (2008). The emergent curriculum: Navigating a complex course between unguided learning and planned enculturation. Journal of Curriculum Studies, 40, 313-328.

Pors, J. G. (2014). Støjende Styring — Genopfindelsen af folkeskolen mellem ledelse, organisering og læring [Noisy Management. The leadership, organisation and teaching in the folkeschool reinvented] (1st ed.). Frederiksberg: Nyt fra Samfundsvidenskaberne.

Pors, J. G., \& Staunæs, D. (2011). Hvordan føles det at tabe i OECD? [How does it feel to fail in OECD?] Unge pædagoger, 3, 27-35.

Reid, A., Jensen, B. B., Nikel, J., \& Simovska, V. (Eds.). (2008). Participation and Learning. Perspectives on education and the environment, health and sustainability. London: Springer.

Samdal, O., \& Rowling, L. (Eds.). (2013). The implementation of health promoting schools: Exploring the theories of what, why and how. London: Routledge Falmer.

Samdal, O., \& Rowling, L. (2015). Implementation strategies to promote and sustain health and learning in school. In V. Simovska \& P. M. McNamara (Eds.), Schools for health and sustainability - Theory, research and practice (pp. 233-252). Dordrecht: Springer.

Schnack, K. (2000). Action competence as curriculum perspective. In B. B. Jensen, K. Schnack, \& V. Simovska (Eds.), Critical environmental and health education (pp. 107-126). Copenhagen: Department of Education, Aarhus University.

Schnack, K. (2008). Participation, education, and democracy: Implications for environmental education, health education, and education for sustainable development. In A. Reid, B. B. Jensen, J. Nikel, \& V. Simovska (Eds.), Participation and learning. Perspectives on education and the environment, health and sustainability (pp. 181-211). Dordrecht: Springer.

Scott, W. (2013). Developing the sustainable school: Thinking the issues through. Curriculum Journal, 24, 181-205.

Simovska, V. (2004). Student participation - Simulation or reality? Health Education, 104, 163-173.

Simovska, V. (2013). The role of health education in addressing the health divide: Evidence from two European health-promotion projects employing a participatory and action-oriented education approach. In V. Barnekow, B. B. Jensen, C. Currie, A. Dyson, N. Eisenstadt, \& E. Melhuish (Eds.), Improving the lives of children and young people, Vol. 2: Childhood (pp. 2-13). Copenhagen: WHO, Regional Office for Europe.

Simovska, V., \& McNamara, P. M. (Eds.). (2015). Schools for health and sustainability - Theory, research and practice. Dordrecht: Springer.

Simovska, V., Nordin, L. L., \& Madsen, K. D. (2015). Health promotion in Danish schools: Local priorities, policies and practices. Health Promotion International. doi:10.1093/heapro/dav009

Smidt, L. (2012). Undersøgelse af seksualundervisningen i grundskole [Mapping of sexuality education in Danish primary and lower secondary schools]. Copenhagen: Danish family planning association. Retrieved March 5, 2015, from http://www.google.dk/url?sa=t\&rct=j\&q=\&esrc= s\&source=web\&cd=1\&ved $=0$ CCAQFjAA\&url=http $\% 3$ A $\% 2 F \% 2 F w w w . s e x o g s a m f u n d . d k \% 2 F A d m i n \%$ 2FPublic\%2FDownload.aspx\%3Ffile\%3DFiles\%252FFiler\%252FBS\%252FUnders\%25C3\%25B8g else\%2Baf\%2Bseksualundervisningen\%2Bi\%2Bgrundskolen\%2B2012.pdf\&ei=RKz9VLWS BMrMPf34gPAI\&usg=AFQjCNEWFe4qSKOBDHSs5JAgY7-ASplhPw\&sig2=clrZOUxwiiWTMq ugnnl3A\&bvm=bv.87611401,d.ZWU

Symons, G. (2008). Practice, barriers and enablers in ESD and EE: A review of the research. Preston Montfort: SEEd.

Törnsén, M. (2009). Successful principal leadership: Prerequisites, processes and outcomes. Umeå: Pedagogiska institutionen, Umeå University. Retrieved April 23, 2014, from http://www.pedag.umu. se/digitalAssets/31/31541_tornsen_monika.pdf [91]

United Nations. (2008). About ESD. Retrieved December 18, 2014, from http://www.desd.org/About\%20 ESD.htm 
United Nations Education, Scientific and Cultural Organization (UNESCO). (2012). Shaping the education of tomorrow, report on the UN Decade of education for sustainable development, abridged. Retrieved April 4, 2014, from http://sustainabledevelopment.un.org/content/documents/919unesco1.pdf

Viig, N. G., Fosse, E., Samdal, O., \& Wold, B. (2011). Leading and supporting the implementation of the Norwegian network of health promoting schools. Scandinavian Journal of Educational Research, $56,671-684$.

Viig, N. G., \& Wold, B. (2005). Facilitating teachers' participation in school-based health promotion: A qualitative study. Scandinavian Journal of Educational Research, 49, 83-109.

Whitman, C. V. (2005). Implementing research-based health promotion programmes in schools: strategies for capacity building. In S. Clift \& B. B. Jensen (Eds.), The health promoting school: International advances in theory, evaluation and practice (pp. 107-135). Copenhagen: University of Education Press.

World Health Organization. (1986, November). The Ottawa charter for health promotion. Retrieved March 25, 2014, from http://www.who.int/healthpromotion/conferences/previous/ottawa/en/

World Health Organization. (2013). The Helsinki statement on health in all policies. The 8th Global Conference on Health Promotion, Helsinki, Finland, 10-14 June. Retrieved March 10, 2015, from http://www.who.int/healthpromotion/conferences/8gchp

Young, I. (2015). Health promotion and sustainable development in schools - Historical perspective. In V. Simovska \& P. M. McNamara (Eds.), Schools for health and sustainability - Theory, research and practice, (pp. 19-40). Dordrecht: Springer.

Zachariou, A., \& Kadji-Beltran, C. (2009). Cypriot primary school principals' understanding of education for sustainable development key terms and their opinions about factors affecting its implementation. Environmental Education Research, 15, 315-342. 